\title{
Statistical Analysis to Evaluate The Service Quality at Community Health Center in Padang, Indonesia
}

\author{
Aidinil Zetra ${ }^{1}$, Ferra Yanuar $^{2}$ \\ ${ }^{1}$ Department of Political Science, Faculty of Social and Political Science, Andalas \\ University, Kampus Limau Manis, 25163, Padang-Indonesia \\ ${ }^{2}$ Department of Mathematics, Faculty of Mathematics and Natural Science, Andalas \\ University, Kampus Limau Manis, 25163, Padang-Indonesia \\ aidinilzetra1@gmail.com
}

\begin{abstract}
Healthcare provider have to take care of patient satisfaction. Therefore, the management should do a kind of evaluation to examine the patient satisfaction on the corresponding services. The purpose of this study is to evaluate the service quality of public health centre and to identify the attributes of services to be improved. This study was cross sectional study conducted by distributing the questionairres to the patients of public health centre in Padang, Indonesia from April to June 2015. This study involved 446 respondents with complete information. Customer Satisfaction Index (CSI) was used to measure the service quality of corresponding public health centre. Importance Performance Analysis (IPA) approach was also applied to identify any attributes to be improved. The respondents of this study were very satisfied with the health service that they ever got. All attributes of service were plotted in four quadrants. This study proved that CSI and IPA methods are pertinent to be applied to measure patient satisfaction and identify any attributes of service to be maintained or improved.
\end{abstract}

Key-words: Patient satisfaction, service quality, public health centre, Customer Satisfaction Index, Importance Performance Analysis.

\section{Introduction}

The evaluation of public service should be done periodically in order to maintain and develop the quality of service at corresponding public sector (Arabatzis \& Grigoroudis, 2010; Bjertnaes, Skudal, \& Iversen, 2013). To achieve this goal, all elements of a service should be evaluated. Thus, management can design the regulation for general evaluation based on community 's need and community's hope. In doing evaluation, it's needed a kind of marking on service quality at corresponding public service. Customer satisfaction is one of method that can be used toestimate the marking on public service [5][10].

Satisfaction is sometimes considered as a judgement of individuals regarding any object or even after gathering some experience. Customer satisfaction is explained as a cognitive response of customers or consumer's evaluation of consumption experience. Customer satisfaction index is an index to measure individual's satisfaction after receiving a service [6][9].

Healthcare is one of the fastest growing service, especially in Indonesia. The growth of health awareness in the community is followed by the growth of knowledge, education level, medical technology and social status of the community. Individu have free choice to decide 
where they get healthcare. They will go the the health centre that best meet their healthcare needs. Therefore, healthcare quality and patient satisfaction are two things that are important and be health outcome and quality measure where patient is as the center of healthcare quality [11].

Thus, it is important to do a study in the aims to do the evaluation to community health centre. This research can give information and evaluation material for management in order to improve the quality of their service to the patients. This study is also purposed to conduct a literature survey to understand how the service quality measures the patient satisfaction.

\section{Literature Reviews}

Many studies have been done regarding to patient satisfaction on quality of healthcare service. Bayraktar et al. (2012) defined consumer satisfaction in terms of the concepts of cognitive and affective dimensions. Meanwhile Manolitzas, Grigoroudis, \& Matsatsinis (2014) defined customer satisfaction as a ratio of customer perception and customer expectation. Miranda et al. (2010) found that one of the principal factors of customer satisfaction is service or product. They also studied that perceived quality is one of the determinants of patient satisfaction.

There were some researchers also identified the indicators that could be implemeted to measure patient satisfaction on healthcare service. Such as a study by Parasuraman, et al. (1988) who suggested a popular model known as SERVQUAL which identified five attributes, i.e., reliability, responsiveness, assurance, emphaty and tangibles. All five attributes were used to measure consumer satisfaction in terms of service quality. Jabbari et al. (2014) identified some indicators in order to measure quality which emphasized on customer's perception and customer's expectation, such as attitude, behaviour, experience (interaction quality), social factors else. A study conducted by Chen, Hsiao, \& Hwang (2012) explained that patient satisfaction was measured by quality that explained in two ways, these are 1) quality as an indicator of individual's satisfaction based on individual's experience on any medical service attributes, such as comfort, security, dignity, privacy and else, 2) quality as an indicator of individual's overall satisfaction on life after receiving medical service.

Scotti, Harmon \& Behson. (2007) also revealed that patient satisfaction was driven by respect and dignity, efficiency and speed, emotional support, comfort, information and communication. Another study conducted in Taiwan was also focus on factors to measure patient satisfaction, this study was done by $\mathrm{Hu}$ et al. (2010). They mentioned that there must be attributes and attractive attributes in measuring patient satisfaction. Comfort, convenience, medical technology, capacity and commitment were the variables of attributes. Meanwhile the attractive attributes consist of variables such as quality of doctors, quality of drug, etc. They measured the patient satisfaction in Taiwan by applying Customer satisfaction Index.

\section{Materials and Methods}

This present study used primary data which collected by distributing the questionnaires to the patients who ever received healthcare at least twice in selected public health service in Padang, West Sumatera, Indonesia. The survey was conducted from March to June 2015. The aims of this research is to measure the level of patient's satisfaction on healthcare service in Padang, Indonesia and to identify the importance and performance of any items based on patient's perception. To achieve both aims, CSI and IPA approach were implemented here [15][16].

\section{6|EKS A K T A : B erkala Ilmiah Bidang MIP A}


In the beginning of the questionnaires, the respondents were asked about their profiles, such as age, education level, their job. Then, the respondents were asked about their satisfaction level on service quality items that break down into 18 items, such as requirements, procedures, time in service, fee, product of service, staffs, etc. A five point Liker scale was used to measure the importance of each item in questionnaire, ranging from 5 (very important) to 1 (very unimportant). The performance of each corresponding item was also measured using five point Liker scale ranging from 5 (very satisfied) to 1 (very unsatisfied). More than 500 questionnaires were distributed to the patients, however only 446 patients of them provided complete information.

CSI method measure customer satisfaction through certain attributes depend on information needed in study. The steps to measure CSI values are 1) calculate the mean of customer's perception on importance of items (MIS) and the mean of customer's satisfaction of items (MSS), 2) calculate weight factor for each customer by comparing MIS of each customer over MIS total, 3) calculate weight score by multipliying weight factor and MSS, 4) calculate CSI from dividing weight score by 5 [15].

IPA was first introduced and proposed by Martilla and James (1977) as a means by satisfaction as the function of two components, they are the importance of a product or a service to a client and the performance of a business in providing the corresponding service or product. Therefore, IPA identifies both performance of an item and importance of that item which both factors indicated as a determining factor in satisfaction to the respondent. Those two factors then combined to provide an overall view of client's satisfaction of that service or product.

The IPA model is presented into quadrants, with performance on the $\mathrm{x}$-axis and importance on the y-axis. There are four quadrants in IPA, quadrant I with high importance and high performance is labeled by "Keep Up the Good Work". Quadrant II with high importance and low performance is indicated by "Concentrate Here". Quadrant III is concluded as "Low Priority" with low importance and low performance. Quadrant IV with low importance and high performance is indicated as "Possible Overkill". Figure 1 below describes all four quadrants in IPA.

\begin{tabular}{|c|c|c|}
\hline & $\begin{array}{c}\text { Quadrant II } \\
\text { "Concentrate Here" }\end{array}$ & $\begin{array}{c}\text { Quadrant I } \\
\text { "Keep Up the Good Work" }\end{array}$ \\
\hline ఏँ & $\begin{array}{l}\text { Quadrant III } \\
\text { "Low Priority" }\end{array}$ & $\begin{array}{c}\text { Quadrant IV } \\
\text { "Possible Overkill" }\end{array}$ \\
\hline
\end{tabular}

Performance

Figure 1. Four Quadrants in IPA

\section{Results}

In the beginning of the analysis, it's presented the characteristic of respondents who involved in the analysis, as showing in the following Table 1. 
Table 1. Respondent's Profile

\begin{tabular}{cccc}
\hline \multirow{2}{*}{ Item } & Classification & Frequency & Percentage (\%) \\
\hline Gender & Male & 187 & 41,9 \\
& Female & 259 & 58,1 \\
Age group & & & \\
& 27 and below & 139 & 31,2 \\
& 28 to 37 & 75 & 16,8 \\
& 38 to 47 & 106 & 23,8 \\
& 48 to 57 & 71 & 15,9 \\
& 58 and above & 55 & 12,3 \\
& & & \\
& Elementary & 57 & 12,8 \\
& Junior high school & 108 & 24,2 \\
& Senior high school & 217 & 48,7 \\
& Diploma & 26 & 5,8 \\
& Bachelor & 37 & 8,3 \\
& Master and above & 1 & 0,2 \\
\hline
\end{tabular}

Table 1 informed us that $58,1 \%$ of all respondents were female and $41,9 \%$ were male. Most respondents in this survey were in the age group of 27 years old and below $(31,2 \%), 23,8 \%$ of them were 38 to 47 years old. Based on education level, most respondents were senior high school $(48,7 \%)$ and only 1 respondent or 0,2 of all respondents had master (or PhD).

Then CSI approach was implemeted in order to measure the satisfaction level of respondents in term of having healthcare at selected healthcare center in Padang, Indonesia. By allowing all steps in calculating CSI as described above, the values for each steps are presented in Table 2. It's informed that this study yielded the CSI value is 87,723 , indicated as "very satisfied". This CSI value here is interpreted that the respondents were very satisfied after having healthcare at any selected health care centers in Padang, Indonesia.

Table 2. CSI Analysis for Importance and Performance of Items in Healthcare

\begin{tabular}{clcccc}
\hline No & \multicolumn{1}{c}{ Items } & $\begin{array}{c}\text { Importance } \\
\text { Average }\end{array}$ & $\begin{array}{c}\text { Weight } \\
\text { Factor }\end{array}$ & $\begin{array}{c}\text { Performance } \\
\text { Average }\end{array}$ & $\begin{array}{c}\text { Weight } \\
\text { Score }\end{array}$ \\
\hline & Requirements & & & \\
\hline 1 & $\begin{array}{l}\text { Information on requirements } \\
\text { is clear }\end{array}$ & 4.336 & 0.031 & 4.074 & 0.124 \\
$2 \quad \begin{array}{l}\text { It's easy to complete the } \\
\text { document } \\
\text { Between requirements and } \\
\text { service are relevan } \\
\text { Procedure }\end{array}$ & 4.517 & 0.032 & 4.242 & 0.135 \\
4 & $\begin{array}{l}\text { Information on procedures is } \\
\text { clear }\end{array}$ & 4.443 & 0.031 & 4.268 & 0.133 \\
& 4.423 & 0.031 & 4.275 & 0.133
\end{tabular}


E-ISSN : 2549-7464, P-ISSN : 1411-3724

\begin{tabular}{|c|c|c|c|c|c|}
\hline 5 & $\begin{array}{l}\text { Easy to follow service } \\
\text { procedures }\end{array}$ & 4.477 & 0.031 & 4.329 & 0.136 \\
\hline 6 & $\begin{array}{l}\text { The procedure for giving } \\
\text { complaints available }\end{array}$ & 4.450 & 0.031 & 4.356 & 0.136 \\
\hline 7 & $\begin{array}{l}\text { The maintenance process in } \\
\text { accordance }\end{array}$ & 4.456 & 0.031 & 4.336 & 0.136 \\
\hline & \multicolumn{5}{|l|}{ Service Time } \\
\hline 8 & $\begin{array}{l}\text { Full schedule certainty and } \\
\text { clear }\end{array}$ & 4.262 & 0.030 & 4.114 & 0.123 \\
\hline 9 & Service time is reasonable & 4.470 & 0.031 & 4.329 & 0.136 \\
\hline \multirow[t]{2}{*}{10} & $\begin{array}{l}\text { The length of service in } \\
\text { accordance with the promised }\end{array}$ & 4.416 & 0.031 & 4.383 & 0.136 \\
\hline & \multicolumn{5}{|l|}{ Service charge } \\
\hline 11 & $\begin{array}{l}\text { Information about cost is } \\
\text { available }\end{array}$ & 4.396 & 0.031 & 4.456 & 0.138 \\
\hline 12 & $\begin{array}{l}\text { Information on payment is } \\
\text { clear }\end{array}$ & 4.510 & 0.032 & 4.470 & 0.142 \\
\hline 13 & Reasonable service charge & 4.430 & 0.031 & 4.510 & 0.141 \\
\hline \multirow[t]{2}{*}{14} & No additional costs & 4.510 & 0.032 & 4.503 & 0.143 \\
\hline & $\begin{array}{l}\text { Specification product } \\
\text { service }\end{array}$ & & & & \\
\hline 15 & $\begin{array}{l}\text { Results of the service in } \\
\text { accordance with established }\end{array}$ & 4.309 & 0.030 & 4.396 & 0.133 \\
\hline 16 & Results could be accepted & 4.490 & 0.032 & 4.436 & 0.140 \\
\hline 17 & All service process are safety & 4.336 & 0.031 & 4.443 & 0.136 \\
\hline & \multicolumn{5}{|l|}{ Competence of officer } \\
\hline 18 & \multirow{4}{*}{$\begin{array}{l}\text { Officers are clear } \\
\text { Officers have good } \\
\text { knowledge } \\
\text { Officers have good skill } \\
\text { Officers have good } \\
\text { experience }\end{array}$} & 4.450 & 0.031 & 4.436 & 0.139 \\
\hline 19 & & 4.430 & 0.031 & 4.369 & 0.136 \\
\hline 20 & & 4.544 & 0.032 & 4.409 & 0.141 \\
\hline \multirow[t]{2}{*}{21} & & 4.436 & 0.031 & 4.510 & 0.141 \\
\hline & \multicolumn{5}{|l|}{ Behavior of officers } \\
\hline 22 & Officers served quickly & 4.430 & 0.031 & 4.349 & 0.136 \\
\hline 23 & Officers are polite & 4.443 & 0.031 & 4.436 & 0.139 \\
\hline 24 & $\begin{array}{l}\text { Officers serving with the } \\
\text { system turn }\end{array}$ & 4.497 & 0.032 & 4.510 & 0.143 \\
\hline 25 & Officers are fair & 4.537 & 0.032 & 4.463 & 0.142 \\
\hline 26 & $\begin{array}{l}\text { Officers willing to help } \\
\text { without being asked }\end{array}$ & 4.570 & 0.032 & 4.470 & 0.144 \\
\hline 27 & Officers are patient & 4.463 & 0.031 & 4.503 & 0.141 \\
\hline 28 & Officers are friendly & 4.336 & 0.031 & 4.369 & 0.133 \\
\hline
\end{tabular}

Service information 
29 Services standard are available

4.436

0.031

4.477

0.031 service standard

4.477

\section{Complaints and suggestions}

This unit provides access to

31 complaints, suggestions and input

32 Complaints advice

32 immediately actionable

Total Score

CSI Value
4.342

0.031

4.503 142.121

0.032

4.329

0.137

4.386

0.138

0.139

After measuring the CSI value, this study want to identify the position of each items based on importance and performance values where obtained from respondent's perception. By applying IPA approach, this following Figure 2 presents the plotting of 32 items in four quadrants.

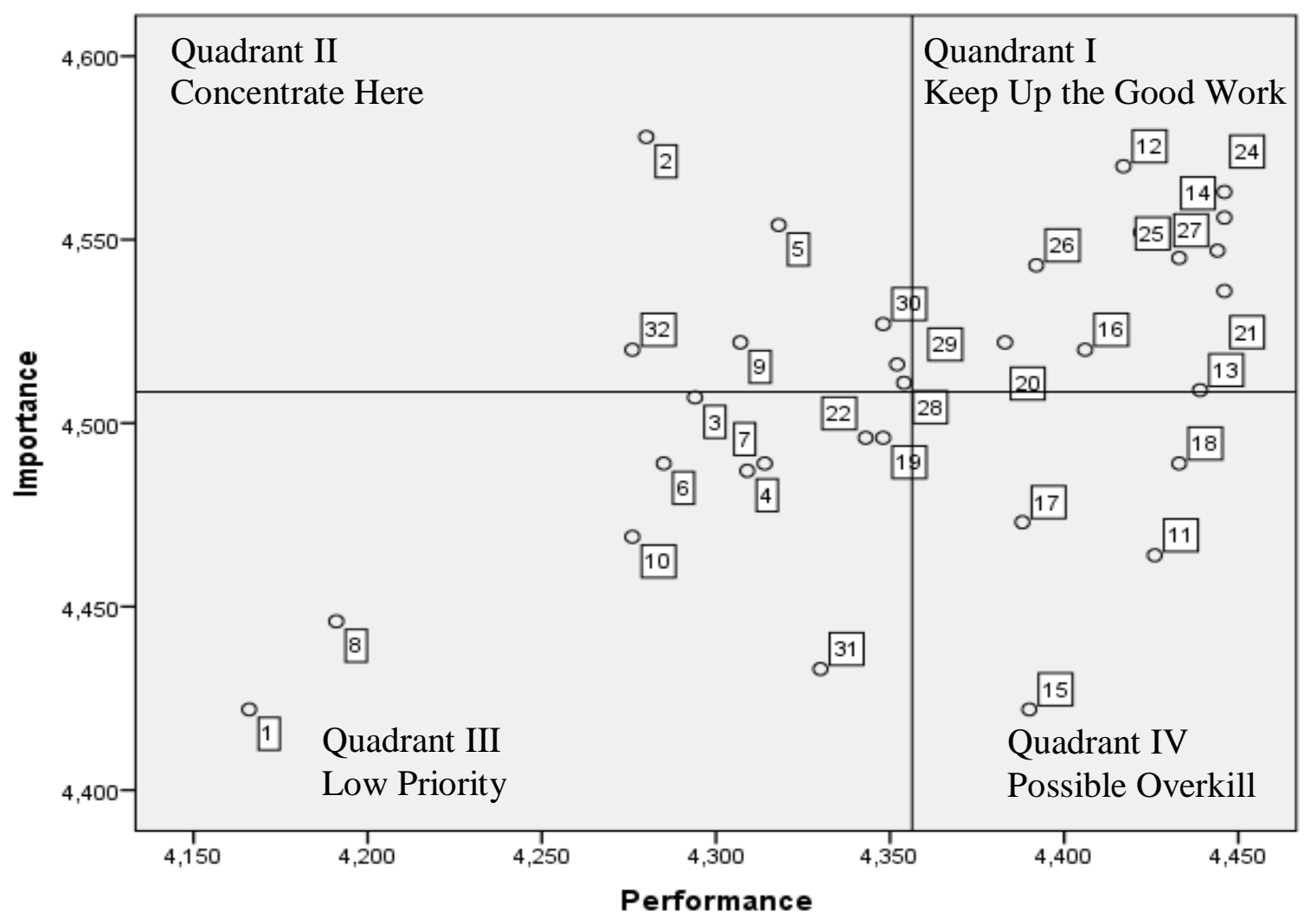

Figure 2. The IPA Grid 
In Figure 2, the x-axis represents respondent's performance perception while the y-axis represents respondent's importance perception. The mean values for overall importance is 4,509, the mean of overall performance is 4.356. Both lines are used to split the axes become four quadrants.

Based on Figure 2, it can be seen that items fall in quadrant I (Keep Up the Good Work ) are items 2, 5, 9, 28, 29, 30 and 32. This quadrant suggests that healthcare centre is doing well and hope could continue the good work in corresponding items. The quadrant II (Concentrate Here) contains items 12, 13, 14, 16, 20, 23, 24, 25, 26 and 27. Items falled inside this quadrant suggest that must improve the performance of those items. The following items located in quadrant III (Low Priority) 1, 3, 4, 6, 7, 8, 10, 19, 22 and 31. The items falled in this area are not important based on respondent's perception and the performance of those items were not also good. Meanwhile items number 11, 15, 17 and 18 falled in quadrant IV (Possible Overkill) that reflect a low priority region.

\section{Conclusions}

The main purpose of the present study is to measure the patient satisfaction level on healthcare service by implementing the methods of customer satisfaction index and importance performance analysis. This research can give information and evaluation material for management in order to improve the quality of their service to the patients. This study is also purposed to conduct a literature survey to understand how the service quality measures the patient satisfaction. In this study, two statistical methods were implemented to real data set regarding to patient satisfaction on healthcare service in Padang, Indonesia.

This study proved that CSI and IPA methods were approprite to be implemented in the data of patient satisfaction. This atudy found that respondents were satisfy after having healthcare services at selected healthcare center in Padang, Indonesia. It was indicated by the value of CSI is 87,723, indicated as "very satisfied". Meanwhile based on IPA, this study identified the plotting of all 32 items in four quadrants. There were 7 items falled in quadrant I, 10 items falled in quadrant II, 10 items in qundrant III and 4 items falled quadrant IV. Those finding are important for managements in order to maintain and improve the quality of their service to the patients [8].

\section{References}

[1] Arabatzis, G., \& Grigoroudis, E. (2010). Visitors' satisfaction, perceptions and gap analysis: The case of Dadia-Lefkimi-Souflion National Park. Forest Policy and Economics, 12(1), 163-172.

[2] Bayraktar, E., Tatoglu, E., Turkyilmaz, A., Delen, D., \& Zaim, S. (2012). Measuring the efficiency of customer satisfaction and loyalty for mobile phone brands with DEA. Expert Systems with Applications, 39(1), 99-106.

[3] Bjertnaes, O., Skudal, K., \& Iversen, H. (2013). Classification of patients based on their evaluation of hospital outcomes: Cluster analysis following a national survey in Norway. BMC Health Services Research, 13(1), 73-81. 
[4] Chen, R., Hsiao, J., \& Hwang, H. (2012). Measuring customer satisfaction of Internet banking in Taiwan: Scale development and validation. Total Quality Management \& Business Excellence, 23(8), 749-767.

[5] Clemes, M., Gan, C., \& Zhang, D. (2010). Customer switching behaviour in the Chinese retail banking industry. International Journal of Bank Marketing, 28(7), 519-546.

[6] Grigoroudis, E., \& Siskos, Y. (2010). Customer satisfaction evaluation methods for measuring and implementing service quality. New York: Springer.

[7] Hu H, Chiu S, Cheng C. \& Hsieh Y. (2010), A study on investigating patient satisfaction of medical centers using Taiwan customer satisfaction index in Taiwan, African Journal of Business Management, 4(14), 3207-3216.

[8] Jabbari, H. et al. (2014). Relationship between Job Satisfacton and Performance of Primary Care Physicians after The Family Physicin Reform of East Azerbaijan Province in Northwest Iran. Indian Journal of Public Health, 58 (4), 256-260.

[9] Karolina Ilieska, (2013). Customer Satisfaction Index - as a Base for Strategic Marketing Management, TEM Journal, 2(4), 327-331.

[10] Lee, F. (2004). If Disney ran your hospital: 9 1/2 things you would do differently. Bozeman, M.T.: Second River Healthcare Press.

[11] Manolitzas, P., Grigoroudis, E., \& Matsatsinis, N. (2014). Using Multicriteria Decision Analysis to Evaluate Patient Satisfaction in a Hospital Emergency Department. Journal of Health Management, 16(2), 245-258.

[12] Martilla, J. A., James, J. C. (1977). Importance-performance analysis. Journal of Marketing, 41: 77-79.

[13] Miranda, FA. Chamorro, Murillo, L., Vega, J. (2010). An Importance-Performance Analysis of Primary Health Care Services: Managers vs. Patients Perceptions. Journal of Service Science and Management, 3(2): 227-234.

[14] Parasuraman A., Berry L .(1988). SERVQUAL : A multiple item scale for measuring consumer perceptions of service quality, Journal of Retail, 1, 12-40.

[15] Rajendran, Prasadh R \& Jayshree S. (2017). Customer Satisfaction Index As A Performance Evaluation Metric: A Study On Indian E-Banking Industry. International Journal of Business, 22 (3) : $12-25$.

[16] Scotti.D.J., Harmon J., Behson. S.J. (2007), Links among High-performance Work Environment, Service Quality and Customer Satisfaction: an Extention to the Healthcare Sector. Journal of Helth Care Mangement, 52(2),109-24. 